\title{
Dimensi Keadilan dalam Partisipasi Penyusunan Anggaran dan Kinerja Manajerial Rumah Sakit
}

\author{
Yana Firana \\ Universitas Hasanuddin \\ yana.firana5@gmail.com
}

\author{
Ahmad Abbas \\ Institut Agama Islam Negeri Parepare \\ ahmad.abbas@stainparepare.ac.id
}

\begin{abstract}
Abstrak Penelitian ini bertujuan untuk menguji dan menganalisis efek keadilan yang didimensikan ke dalam keadilan distributif, prosedural, dan interaksional terhadap hubungan partisipasi penyusunan anggaran dan kinerja manajerial rumah sakit. Sampel penelitian adalah pegawai rumah sakit yang terlibat dalam proses penyusunan anggaran yang ada di Sulawesi Selatan. Data dianalisis kedalam analisis jalur dengan multiple mediators. Hasil penelitian ini mengungkapkan bahwa partisipasi anggaran menyediakan efek langsung terhadap peningkatan kinerja manajerial rumah sakit. Pada efek mediasi, dimensi keadilan mendorong efek kenaikan partisipasi anggaran terhadap kinerja manajerial rumah sakit.

Kata Kunci Partisipasi Anggaran, Kinerja Manajerial, Dimensi Keadilan, Rumah Sakit
\end{abstract}

\section{PENDAHULUAN}

Rumah sakit sebagai unit sosial dihadapkan pada semakin langkanya sumber dana untuk membiayai kebutuhannya dan harus bekerja dengan tarif yang dapat terjangkau oleh masyarakat luas. Rumah sakit pemerintah merupakan unit kerja dari instansi pemerintah yang memberikan pelayanan kesehatan kepada masyarakat umum. Permasalahan yang selalu timbul adalah sulitnya meramalkan kebutuhan pelayanan yang diperlukan masyarakat maupun kebutuhan sumber daya untuk mendukungnya. Di lain pihak rumah sakit harus siap setiap saat dengan sarana, prasarana tenaga maupun dana yang dibutuhkan untuk mendukung pelayanan tersebut.

Penganggaran merupakan aktivitas yang menghasilkan anggaran sebagai suatu hasil kerja (Bastian, 2009). Sebagai pedoman kerja, anggaran memberikan arah sekaligus memberikan target yang harus dicapai oleh kegiatan rumah sakit pada waktu yang akan datang. Sebagai alat koordinasi, anggaran mengkoordinasikan semua bagian yang ada di rumah sakit sehingga saling menunjang, saling bekerja sama dengan baik untuk menuju sasaran yang telah ditetapkan.

Partisipasi penyusunan anggaran adalah sejauh mana anggaran dipengaruhi oleh keterlibatan para pengurus, alasan-alasan pihak manajer pada saat anggaran diproses, keinginan memberikan partisipasi anggaran kepada pihak manajer tanpa diminta, sejauh 
mana manajer mempunyai pengaruh dalam anggaran akhir.Partisipasi adalah keterlibatan individu yang bersifat mental dan emosional dalam situasi kelompok bagi pencapaian tujuan bersama dan berbagi tanggung jawab bersama. Partisipasi yang diberikan oleh individu bukan hanya aktivitas fisik tetapi juga sisi keadilan, yaitu seberapa besar pengaruh seseorang dalam pengambilan keputusan. Dalam dimensi keadilan distributif, wilayah tanggung jawab dalam menerima anggaran harus jelas dan sesuai, anggaran dialokasikan untuk wilayah tanggung jawab secara memadai mencerminkan kebutuhan dan keadilan, serta ada keprihatinan dan sensitivitas diungkapkan secara terbuka oleh atasan ketika mendiskusikan pembatasan anggaran. Pada dimensi keadilan prosedural, prosedur penganggaran diterapkan secara konsisten di semua wilayah pertanggungjawaban. Keputusan anggaran untuk wilayah pertanggungjawaban yang didasarkan pada informasi yang akurat dan pendapat yang diinformasikan dengan baik dan prosedur penganggaran yang dianggap sesuai dengan standar etik dan moralitas. Sementara dimensi keadilan interaksional berhubungan dengan perasaan yang dirasakan seseorang apakah sudah diperlakukan adil dalam implementasi prosedur. Dalam penyusunan anggaran manajer harus mendelegasikan masing-masing pekerjaan kepada pelaksana/ bawahan secara adil sesuai dengan tanggung jawab masing-masing karyawan. Partisipasi karyawan dalam penyusunan anggaran jika dikaitkan dengan keadilan interaksional sangat dibutuhkan agar manajer dapat mengetahui benar tanggung jawab dari masing-masing pelaksana/ bawahan, sehingga tidak terjadi overlapping dalam pekerjaan dan tidak ada yang merasa dirugikan (Hasniasari \& Sholihin, 2014).

Ketika seseorang terlibat dalam pengambilan keputusan penganggaran, maka ia akan termotivasi dalam situasi kelompok karena diberi kesempatan untuk mewujudkan inisiatif dan daya kreatifitas. Tujuan bersama akan lebih mudah tercapai sehingga ada keterlibatan secara pribadi dan kesediaan untuk menerima tanggung jawab masingmasing. Rasa tanggung jawab ini pada akhirnya akan memperkuat kreativitas manajer yang bersangkutan. Partisipasi penyusunan anggaran, karyawan akan dilibatkan keberadaannya dan tidak sekedar terlibat dengan job description yang dikerjakan. Keikutsertaan dalam penyusunan anggaran manajer akan lebih memahami masalah yang timbul pada saat pelaksanaan anggaran.

Partisipasi penyusunan anggaran dinilai sebagai pendekatan manajerial yang dapat meningkatkan kinerja organisasi. Partisipasi dalam penyusunan anggaran diharapkan setiap individu mampu meningkatkan kinerjanya sesuai dengan target yang ditetapkan sebelumnya (Giri, 2014; Mediaty, 2010; Muhlis, 2012; Sardjito \& Muthaher, 2007; Wahyuningsih et al., 2012). Tingkat keikutsertaan bawahan dalam pengambilan keputusan dalam proses penyusunan anggaran adalah faktor utama yang menjelaskan partisipasi penyusunan anggaran (Tapatfeto, 2013). Sasaran untuk menetapkan tujuan adalah tingkat kinerja yang ingin dicapai. Jika seseorang adil dalam mencapai tujuan, itu akan mempengaruhi tindakannya sehingga ikut mempengaruhi kinerja. Terlebih lagi, jika dimensi keadilan yang terdiri dari keadilan distibutif, keadilan prosedural, dan keadilan interaksional telah memiliki peranan penting yang akan berpengaruh signifikan terhadap peningkatan kinerja manajerial.

Partisipasi penyusunan anggaran merupakan pendekatan yang secara umum dapat meningkatkan kinerja yang pada akhirnya dapat meningkatkan efektivitas organisasi. Keefektifan kinerja manajerial dapat dilihat dari pencapaian tujuan anggaran (budgeting goal). Kejelasan tujuan anggaran dapat memudahkan penyusunan rencana kegiatan organisasi dan menentukan kualitas fungsi-fungsi organisasi sehingga anggaran dapat 
dijadikan tolok ukur pencapaian kinerja. Sebaliknya, menurut Mardiasmo (2009), jika anggaran tidak efektif dan tidak berorientasi pada kinerja maka akan menggagalkan setiap perencanaan program dan aktivitas yang telah disusun.

Hal-hal yang berkaitan dengan anggaran (khususnya terkait partisipasi anggaran) dan kinerja telah diteliti secara luas namun kebanyakan bukti-bukti empiris memberikan hasil yang bervariasi dan tidak konsisten. Di antaranya adalah penelitian Kenis (1979) \& Brownel (1982) dan Winata \& Mia (2005) yang menemukan bahwa partisipasi penganggaran kinerja memiliki hubungan yang sangat positif. Namun, penelitian Sterdy (1960) \& Milani (1975) serta Chalos \& Poon (2000) menemukan bahwa partisipasi penyusunan anggaran tidak mempengaruhi kinerja. Di Indonesia, penelitian mengenai penganggaran dan kinerja juga terus dikembangkan, baik di sektor privat (Damayanti, 2007; Indarto, 2011) maupun di instansi pemerintah (Muhlis, 2012, Munawar et al., 2006; Mediaty, 2010; Nadirsyah et al., 2012; Sardjito \& Muthaher, 2007; Setyowati \& Purwantoro, 2013; Wahyuningsih et al., 2012). Hasil penelitian yang bervariasi dan tidak konsisten tersebut merupakan indikasi bahwa ada faktor lain yang mempengaruhi hubungan anggaran dan kinerja. Faktor tersebut merupakan faktor yang sifatnya situasional atau yang disebut sebagai faktor kontinjensi, seperti budaya organisasi, komitmen organisasi, nilai organisasi, gaya kepemimpinan, motivasi dan ketidakpastian lingkungan lainnya.

Salah satu faktor kontinjensi yang juga mempengaruhi hubungan anggaran dan efektivitas pencapaian kinerja adalah aspek keadilan dalam lingkungan kerja. Keadilan memiliki peran penting terhadap peningkatan kinerja karyawan (Hidayah \& Haryani, 2013). Sebagai contoh, deskripsi pekerjaan kepada pelaksana (bawahan) secara adil sesuai dengan tanggung jawabnya masing-masing agar pelaksana dalam implementasinya tidak ada yang saling menuduh dan menyudutkan. Adanya overlapping pekerjaan terkadang membuat pelaksana merasa dirugikan. Selain itu, untuk meningkatkan kinerja manajerial, manajer sebaiknya memperkenankan partisipasi dalam penyusunan anggaran dengan prosedur yang adil (Ogiedu \& Odia, 2013). Dengan demikian, peran keadilan secara tidak langsung memungkinkan untuk mencapai kinerja yang efektif.

Peran keadilan terhadap kinerja manajerial menarik untuk diuji. Sejauh ini, pengujian keduanya sangat luput mengidentifikasi peran keadilan dalam pencapaian kinerja. Bawono (2008) telah menguji salah satu dimensi keadilan, yaitu peran keadilan prosedural dalam hubungan antara karakteristik tujuan anggaran dan kinerja manajerial pada instansi pemerintah daerah di Surakarta. Keadilan prosedural merupakan salah satu dimensi keadilan yang menekankan pada prosedur. Hasil penelitian tersebut menunjukkan bahwa keadilan prosedural berpengaruh terhadap hubungan kedua variabel tersebut secara tidak langsung dari setiap proses yang digunakan dalam mengambil keputusan. Pada perusahaan manufaktur, Ogiedu \& Odia (2013) menyimpulkan bahwa peran keadilan prosedural mampu memperkuat hubungan antara partisipasi anggaran dan kinerja manajerial.

Keadilan distributif juga merupakan salah satu dimensi keadilan. Tulus (2014) menguji secara parsial dimensi tersebut bersama dengan partisipasi anggaran, dan keadillan prosedural terhadap kinerja. Hasilnya menunjukkan bahwa partisipasi anggaran tidak berpengaruh terhadap kinerja manjerial di RSUD Dr. Adhyatma Semarang. Begitu pula, keadilan distributif dan keadilan prosedural tidak berpengaruh terhadap kinerja manajerial. Di samping itu, saat kondisi keadilan belum tercapai, menurut Tulus (2014) hal tersebut tidak menyebabkan terganggunya pekerjaan atau mengurangi kualitas kerja. 
Selanjutnya Giri (2014) melakukan penelitian yang sama dengan Tulus (2014) di RSUP Sanglah Bali namun hasilnya malah menunjukkan bahwa keadilan distributif dan keadilan prosedural memediasi hubungan antara partisipasi anggaran dan kinerja manajerial. Dalam artian, dimensi keadilan berpengaruh positif dalam memediasi hubungan antara partisipasi anggaran dan kinerja RSUP Sanglah Bali.

Pertentangan hasil menyebabkan penelitian lanjutan perlu dilakukan untuk mencapai konsistensi hasil. Di samping itu, penelitian ini akan mengidentifikasi dimensi keadilan yang tidak hanya diidentifikasi dari dimensi distributif dan prosedural seperti penelitian sebelumnya, melainkan keadilan perlu diidentifikasi dari dimensi interaksional yang kemudian ketiga dimensi keadilan tersebut memiliki peran dalam membentuk keadilan secara menyeluruh pada suatu organisasi (Ambrose dan Schiminke, 2011). Berangkat dari penelitian Tulus (2014) dan Giri (2014) dengan objek penelitian di rumah sakit, maka penelitian ini akan berfokus pada peran keadilan yang didimensikan dari keadilan distributif, prosedural, dan interaksional. Ketiga dimensi keadilan tersebut diharapkan berpengaruh dalam memediasi hubungan partisipasi anggaran dan kinerja manajerial pada organisasi pelayanan masyarakat, yaitu rumah sakit. Karenanya, penelitian ini akan mengambil rumah sakit sebagai sampel penelitian. Perbedaan penelitian sebelumnya, penelitian ini dilakukan pada beberapa rumah sakit daerah di Sulawesi Selatan dan mempertimbangkan variabel keadilan interaksional sebagai dimensi keadlian. Beberapa rumah sakit yang menjadi sampel penelitian adalah Rumah Sakit Daerah Barru, Rumah Sakit Daerah Pangkep dan Rumah Sakit Daerah Maros. Pengambilan objek penelitian di rumah sakit umum daerah tersebut, di sisi lain disebabkan adanya tuntutan yang lebih besar dari masyarakat agar rumah sakit tersebut lebih efisien, transparan dan akuntabel dalam memperhitungkan biaya ekonomi dan biaya sosial serta dampak negatif atas aktivitas yang dilakukannya sebagai salah satu manifestasi lembaga sektor publik. Sebagai instansi yang berorientasi pada pelayanan kesehatan publik, rumah sakit dituntut untuk memaksimalkan pelayanan yang idealnya tidak mengkomersialkan jasa sehingga biaya perlu diminimalkan.

Sesuai dengan aturan pemerintah, pada awal tahun 2016 semua rumah sakit daerah di Sulawesi Selatan sudah menjadi BLU (Badan Layanan Umum). Pelayanan yang maksimal diharapkan akan tercipta dari adanya kebijakan tersebut. Namun, pelayanan yang maksimal tentu membutuhkan perencanaan dan pengawasan biaya terlebih lagi pada rumah sakit yang sudah menjadi BLU.

Selain itu, dibutuhkan peningkatan kinerja manajerial yang dilakukan secara efektif di rumah sakit sebagai salah satu cara mempertahankan akreditasi tersebut, salah satunya dengan melibatkan bawahan dalam penyusunan anggaran.Dengan terakreditasinya, manajer dituntut untuk menjalankan fungsi-fungsi manajerial. Dengan demikian, penelitian ini bermaksud untuk menguji peran keadilan yang diidentifikasi dari tiga dimensi, yaitu keadilan distributif, keadilan prosedural, dan keadilan interaksional sebab setiap dimensi keadilan berperan dalam merefleksikan partisipasi anggaran yang selanjutnya diharapkan mempengaruhi kinerja pelayanan kesehatan.

Temuan penelitian ini menyediakan kontribusi teoretis dan praktis. Penelitian ini secara teoretis memperkuat konsistensi hasil empiris mengenai pengaruh partisipasi penyusunan anggaran dan dimensi keadilan terhadap kinerja dan dampak peran dimensi keadilan sebagai faktor kontinjensi dalam memediasi pengaruh partisipasi penganggaran dan kinerja manajerial.Hasil penelitian ini dapat berkontribusi praktis kepada beberapa Rumah sakit umum daerah di Sulawesi Selatan diantaranya Rumah sakit Pangkep, Maros, 
Soppeng dan Barru. Adanya partisipasi penyusunan anggaran diharapkan akan meningkatkan kinerja manajerial terutama dengan memperhatikan dimensi keadilan dalam meningkatkan mutu pelayanan rumah sakit.

\section{LANDASAN TEORI}

\subsection{Partisipasi Penyusunan Anggaran dan Kinerja Manajerial}

Hubungan antara partisipasi penyusunan anggaran dan kinerja manajerial dapat dipandang dari keterlibatan pihak dalam proses penetapan tujuan. Teori penetapan tujuan mendasari hubungan keduanya. Teori penetapan tujuan menunjukkan bahwa keterlibatan manajer dalam proses penganggaran akan mempengaruhi harapan yang diterima atas outcome (Susmitha, 2012). Robbins \& Judge (2008) menyatakan bahwa teori penetapan tujuan menjelaskan hubungan tujuan yang ditetapkan dengan kinerja. Kinerja pegawai yang baik dalam menyelenggarakan pelayanan publik diidentikkan sebagai tujuannya. Sasaran untuk menetapkan tujuan adalah tingkat kinerja yang ingin dicapai. Jika seseorang berkomitmen mencapai tujuan, itu akan mempengaruhi tindakannya sehingga ikut mempengaruhi kinerja. Penelitian terdahulu menunjukkan ketidakonsistenan hasil antara hubungan partisipasi penyusunan anggaran dan kinerja manajerial di rumah sakit. Sardjito \& Muthaher (2007) menemukan partisipasi penyusunan anggaran memiliki pengaruh positif terhadap kinerja manajerial. Mediaty (2010) juga menemukan bahwa partisipasi penyusunan anggaran berpengaruh positif dan signifikan terhadap kinerja aparatur pemerintah daerah. Muhlis (2012) dan Wahyuningsih et al. (2012) juga menemukan hasil yang sama bahwa partisipasi penganggaran berpengaruh positif dan signifikan terhadap kinerja manajerial aparat pemerintah daerah. Semakin tinggi partisipasi anggaran, semakin meningkat kinerja pemerintahan. Tidak sejalan dengan hasil tersebut, Setyowati dan Purwantoro (2013) ternyata menemukan bahwa partisipasi dalam penyusunan anggaran tidak berpengaruh terhadap kinerja manajerial. Semakin seringnya bawahan dilibatkan dalam penyusunan anggaran di instansi pemerintahan, tidak selalu menunjukkan kinerja manajerial yang lebih baik. Sebaliknya semakin jarangnya bawahan yang berpartisipasi dalam penyusunan anggaran, tidak selalu menunjukkan kinerja manajerial yang lebih buruk.

Objek penelitian secara khusus di rumah sakit. Subagiyo (2004) menemukan bahwa partisipasi penyusunan anggaran berpengaruh positif terhadap kinerja manajerial rumah sakit. Giri (2014) menunjukkan hasil yang sama. Peran manajer dalam penyusunan anggaran lebih mengacu sejauh mana manajer berpartisipasi dalam penyusunan anggaran dan mempengaruhi sasaran untuk mencapai tujuan kinerja manajerial. Para manajer lebih termotivasi untuk meningkatkan kinerja manajerial sesuai dengan anggaran, di mana mereka terlibat dalam proses penyusunannya dan menerima pendelegasian wewenang yang relatif besar dalam pembuatan keputusan yang berkaitan dengan anggaran. Tulus (2014) menunjukkan hasil yang berbeda bahwa partisipasi dalam penyusunan anggaaran tidak berpengaruh terhadap kinerja manajerial RSUD Dr. Adhyatma Semarang. Hasil yang tidak signifikan menunjukkan partisipasi yang terjadi belum melibatkan pihak bawahan.

Teori penetapan tujuan yang dikembangkan oleh Locke \& Bryan (1968) yang kemudian diuraikan lagi oleh Robbins \& Judge (2008) mendasari hubungan antara partisipasi penyusunan anggaran terhadap kinerja. Teori penetapan tujuan menganggap bahwa perilaku individu diatur oleh ide seseorang. Sasaran untuk menetapkan tujuan 
adalah tingkat kinerja yang ingin dicapai. Jika seseorang berkomitmen mencapai tujuan, itu akan mempengaruhi tindakannya sehingga ikut mempengaruhi kinerja. Penyusunan anggaran partisipatif diharapkan kinerja manajerial akan meningkat. Segel \& Marchoni (1989) yang selanjutnya ditemukan juga Tapatfeto (2013) menyatakan bahwa partisipasi manajer dalam penyusunan anggaran akan menciptakan inisiatif bagi mereka untuk menyumbangkan ide dan informasi sehingga kinerjaantaranggota sama dalam meningkatkan pencapaian tujuan. Keikutsertaan dalam penyusunan anggaran adalah cara efektif untuk menciptakan keselarasan tujuan setiap pusat pertanggungjawaban dengan tujuan organisasi secara menyeluruh. Dengan demikian, semakin tinggi partisipasi anggaran, semakin meningkat kinerja manajerial. Berdasarkan uraian di atas, hipotesis penelitian dinyatakan sebagai berikut.

H1: partisipasi penyusunan anggaran berpengaruh positif terhadap kinerja manajerial

\subsection{Dimensi Keadilan dan Kinerja Manajerial}

Teori keadilan merupakan dasar dari dimensi keadilan organisasional. Dimensi keadilan terdiri dari hasil, proses, dan interaksi. Ketiga dimensi itu membentuk keadilan secara menyeluruh. Keadilan distributif mengacu bentuk keadilan bagaimana sumber daya dan penghargaan dialokasikan atau didistribusikan. Keadilan prosedural mengacu pada bentuk keadilan dari prosedur dan proses yang digunakan untuk membuat suatu alokasi keputusan. Sedangkan keadilan interaksional berhubungan dengan perasaan yang dirasakan seseorang apakah sudah diperlakukan adil disaat implementasi prosedur. Ketiga dimensi keadilan tersebut memiliki peran dalam membentuk keadilan secara menyeluruh pada suatu organisasi (Ambrose \& Schiminke, 2011).

Tulus (2014) menemukan bahwa keadilan distributif tidak berpengaruh terhadap kinerja manajerial, karakteristik lingkungan kerja yang birokratis di pemerintah daerah membuat persepsi yang dimiliki masih lemah dalam memberikan motivasi untuk meningkatkan kinerjanya. Namun demkian, Idealnya, keadilan distributif yang dirasakan oleh seseorang tentunya akan berakibat pada kinerja. Wilayah tanggung jawab dalam menerima anggaran yang sesuai dan dialokasikan secara tepat (distributif) mendorong peningkatan kinerja.

H2: keadilan distributif berpengaruh positif terhadap kinerja manajerial

Tulus (2014) juga menemukan bahwa dimensi keadilan prosedural yang tidak berpengaruh terhadap kinerja manajerial menunjukkan bahwa ketika kondisi keadilan belum tercapai tidak menyebabkan terganggunya pekerjaan atau mengurangi kualitas kerjanya, serta akan memilih tetap bertahan. Walaupun demikian, penerapan prosedur yang diterapkan secara konsisten dan sesuai dengan standar etik dan moralitas (prosedural) memberikan informasi yang akurat disampaikan dengan baik dan kepercayaan dari atasan ke bawahan menjadi dimensi dari konsep keadilan yang diharapkan akan mempengaruhi kinerja manajerial di rumah sakit.

H3: keadilan prosedural berpengaruh positif terhadap kinerja manajerial

Bawahan harus memegang amanah yang diberikan oleh atasan sehingga bawahan bisa dipercaya oleh atasan. Sebaliknya, bawahan akan percaya kepada pemimpinnya, jika atasan menunjukkan kinerja yang baik dan konsisten dengan apa yang dijanjikannya. 
Interaksi antara bawahan dan pimpinan mendorong kerjasama yang baik sehingga meningkatkan kinerja manajerial.

\section{H4: keadilan interaksional berpengaruh positif terhadap kinerja manajerial}

\subsection{Dimensi Keadilan, Partisipasi Penyusunan Anggaran, dan Kinerja Manajerial}

Penetapan penyusunan anggaran pada awal kegiatan mengharuskan semua anggota organisasi mengarahkan segala kegiatan sesuai tujuan yang telah ditetapkan. Manajemen pada fungsi perencanaan dalam hal ini dituntut untuk memperhatikan penggunaan sumber-sumber ekonomi yang efisien. Dalam keterlibatan tersebut, para manajer harus mengetahui seberapa besar kemampuan yang dimilikinya untuk mencapai target yang akan dicapai, agar dalam diri manajer timbul perasaan yang dihargai, dipercaya sehingga mengakibatkan ada rasa kepuasan atas pekerjaan. Keterlibatan seseorang dalam proses penyusunan anggaran tentunya tidak terlepas dari aspek perilaku, diantaranya rasa khawatir atau cemburu, serta rasa kepuasan dari masing-masing individu sebagai akibat dari adanya kenaikan atau disetujuinya usulan yang ditawarkan.

Suatu organisasi cenderung menginginkan keadilan dalam proses bisnisnya. Pendekatan yang dilakukan dengan cara yang berbeda terhadap keadilan akan sangat berguna untuk menjelaskan bermacam perilaku dalam konteks organisasi pada saat ini. Didasarkan pada teori kontijensi, peran dimensi keadilan kemungkinan menjadi variabel penentu yang saling berpengaruh untuk meningkatkan kinerja manajerial. Hasil penelitian Wentzel (2002) menunjukkan bahwa persepsi keadilan individual meningkat seiring keterlibatan dalam proses anggaran. Jika manajer terlibat dalam proses penganggaran, maka manajer dapat terlibat dalam penentuan keputusan alokasi anggaran.

Giri (2014) menemukan bahwa partisipasi penganggaran berpengaruh pada kinerja manajerial dengan keadilan distributif sebagai variabel pemediasi. Hal ini berarti keadilan distributif mampu memediasi hubungan antara partisipasi penganggaran dengan kinerja manajerial. Peningkatan partisipasi penganggaran yang melibatkan manajer tingkat menengah akan mengakibatkan peningkatanpersepsi keadilan distibutif, yang pada akhirnya akan mengakibatkan peningkatan kinerja manajerial. Semakin tinggi partisipasi manajer dalam penganggaran maka persepsi manajer tingkat menengah pada keadilan distributif yang dirasakan akan semakin meningkat, kemudian peningkatan persepsi manajer pada keadilan distributif akan meningkatkan kinerja manajerial dari manajer.

H5: keadilan distributif memediasi pengaruh partisipasi penyusunan anggaran terhadap kinerja manajerial

Partisipasi selama proses penganggaran tidak menjamin manajer akan menerima anggaran yang mereka inginkan terutama saat langkanya sumber daya, namun partisipasi penganggaran akan meningkatkan pemahaman mereka tentang bagaimana anggaran tersebut dialokasikan (Wentzel, 2002). Saat tingkat pencapaian anggaran dipandang sebagai outcome dan proses dilakukan dengan tepat, kemampuan dan usaha untuk mencapai anggaran dapat dilihat sebagai masukan. Saat kemampuan dan usaha serta pemahaman dicocokkan dengan tingkat pencapaian anggaran, keadilan distributif, keadilan prosedural, dan keadilan interaksional akan terjadi. partisipasi penganggaran berpengaruh pada kinerja manajerial dengan keadilan prosedural sebagai variabel pemediasi. Hasil pengujian menunjukkan bahwa hipotesis kedua dapat diterima. Hal ini berarti keadilan prosedural mampu memediasi hubungan antara partisipasi penganggaran 
dengan kinerja manajerial. Peningkatan partisipasi penganggaran yang melibatkan manajer tingkat menengah, akan mengakibatkan peningkatan persepsi keadilan prosedural, yang pada akhirnya akan mengakibatkan peningkatan kinerja manajerial.

H6: keadilan prosedural memediasi pengaruh partisipasi penyusunan anggaran terhadap kinerja manajerial

Greenberg (1990) serta Hasniasari \& Sholihin (2014) menyatakan pemahaman kepada atasan mendorong keadilan interaksional. Persepsi keadilan interaksional yang timbul dari proses partisipasi penganggaran akan mempengaruhi penerimaan pihak yang terlibat dalam partisipasi tersebut terhadap target yang ditetapkan dalam anggaran. Penerimaan yang dimaksud mengarah kepada peningkatan kinerja. Apabila seseorang diberikan kewenangan berpartisipasi dalam penyusunan anggaran, orang itu akan berusaha memahami tujuan yang direncanakan. Semakin tinggi partisipasi adanya peningkatan partisipasi penyusunan anggaran yang melibatkan partisipasi bawahan akan mengakibatkan peningkatan persepsi keadilan interaksional yang pada akhirnya akan mempengaruhi peningkatan kinerja.

H7: keadilan interaksional memediasi pengaruh partisipasi penyusunan anggaran terhadap kinerja manajerial

\section{METODOLOGI PENELITIAN}

Penelitian ini adalah penelitian kuantitatif. Jenis penelitian yang digunakan adalah penelitian eksplanatori, yaitu penelitian yang menggabungkan beberapa variabel penelitian yang telah diuji sebelumnya. Pengumpulan data penelitian ini menggunakan desain survei dengan memberikan kuesioner kepada responden (Tabel 1).

Populasi adalah sekelompok orang, kejadian atau segala sesuatu yang memiliki karakteristik tertentu (Indriantoro \& Supomo, 2014). Karakteristik tertentu yang ditetapkan oleh peneliti untuk dipelajari kemudian ditarik kesimpulannya (Sugiyono, 2009). Sampel adalah bagian dari karakteristik yang dimiliki oleh populasi tersebut. Populasi yang digunakan dalam penelitian ini adalah seluruh pegawai rumah sakit umum di Sulawesi Selatan. Sampel diambil dengan menggunakan metode purposive sampling, yaitu metode pengambilan sampel yang dilakukan sesuai dengan tujuan penelitian yang ditetapkan. Kriteria yang digunakan dalam penelitian ini adalah sebagai berikut.

1) Karyawan yang memiliki jabatan (kepala bidang/kepala bagian/kepala unit dan kepala sub bidang/kepala sub bagian/kepala sub unit).

2) Menduduki jabatan tersebut minimal 3 tahun.

3) Terlibat dalam proses penyusunan anggaran.

Tabel 1. Rincian Populasi Penelitian

\begin{tabular}{|c|c|}
\hline Objek & Responden \\
\hline Barru & 30 \\
\hline Pangkep & 35 \\
\hline Maros & 20 \\
\hline Soppeng & 25 \\
\hline Pinrang & 30 \\
\hline Jumlah & 140 \\
\hline
\end{tabular}

Sumber. Data Observasi 
Kriteria tersebut dibuat karena umumnya anggaran dibuat setahun sekali sehingga setidaknya karyawan yang memiliki jabatan (kepada bidang/kepala bagian/kepala unit dan kepala sub bidang/kepala sub bagian/kepala sub unit) yang ikut dalam proses penyusunan anggaran.Pengampilan sampel dalam penelitian ini akan dilakukan secara acak. Penentuan jumlah sampel yang diambil dengan menggunakan rumus Slavin (2009) dengan tingkat kepercayaan $95 \%$ adalah sebagai berikut.

$$
\begin{aligned}
\mathrm{n} & =\mathrm{N} / 1+\left(\mathrm{N} \cdot \mathrm{e}^{2}\right) \\
& =140 / 1+\left(140 \times 0,05^{2}\right) \\
& =103
\end{aligned}
$$

Keterangan:

$\mathrm{n}=$ Sampel

$\mathrm{N}=$ Populasi

$\mathrm{e}=$ standar error

Objek penelitian terdiri dari lima rumah sakit umum di Sulawesi Selatan yang terdiri dari RSUD Pangkep, RSUD Barru, RSUD Soppeng, RSUD Pinrang dan RSU Maros. Data penelitian dikumpulkan dengan menyebarkan kuesioner kepada pegawai rumah sakit yang ikut dalam proses penyusunan anggaran. Penelitian ini menyebarkan 103 kuesioner. Ada 55 kuesioner yang tidak kembali. Dengan demikian, jumlah kuesioner yang diterima adalah 48 kuesioner.

\section{Variabel Penelitian}

Variabel dalam penelitian ini terdiri dari variabel dependen, variabel independen, dan variabel mediasi.

\section{Partisipasi Anggaran}

Partisipasi anggaran didefinisikan sebagai keterlibatan dan pengaruh individu dalam proses penyusunan anggaran ( Bastian, 2009). Partisipasi anggaran diukur dengan menggunakan pertanyaan yang menggambarkan penyusunan anggaran, permintaan anggaran ke pimpinan, pembuatan rencana anggaran akhir tahun, dan usulan penyusunan Rencana Kegiatan dan Anggaran (RKA). Instrumen yang digunakan untuk mengukur partisipasi anggaran mengikuti Milani (1975) yang kemudian diikuti oleh beberapa penelitian mutakhir dari Giri (2014), Subagiyo (2004), dan Tulus (2014) yang mengambil objek penelitian di rumah sakit. Ada enam item pertanyaan untuk mengukur partisipasi anggaran.

\section{Dimensi Keadilan}

Tiga dimensi keadilan adalah keadilan distributif, keadilan prosedural, dan keadilan interaksional. Kreitner dan Kinicki (2010) menjelaskan bahwa keadilan distributif merefleksikan bentuk keadilan bagaimana sumber daya dan penghargaan dialokasikan atau didistribusikan. Keadilan prosedural didefinisikan sebagai bentuk keadilan dari prosedur dan proses yang digunakan untuk membuat suatu alokasi keputusan. Sedangkan keadilan interaksional berhubungan dengan perasaan yang dirasakan seseorang apakah sudah diperlakukan adil di saat implementasi prosedur. Dengan demikian, keadilan diukur pada masing-masing dimensinya sebagai berikut.

1. Keadilan distributif didefinisikan sejauh mana karyawan mempersepsikan keadilan dari outcome yang mereka terima dibandingkan dengan pelaksana yang lain karena hal 
yang ditekankan adalah distribusi yang diterima, terlepas dari bagaimana distribusi tersebut ditentukan.

2. Keadilan prosedural didefinisikan sebagai keadilan yang dirasakan melalui kebijakan dan prosedur yang digunakan dalam membuat keputusan dalam lingkungan kerja, seperti dalam proses pengambilan keputusan. keadilan prosedural tersebut akan menyebabkan seseorang akan menerima suatu keputusan, walaupun tidak setuju dengan hasil keputusan tersebut, karena proses pengambilan keputusan dilakukan secara adil.

3. Keadilan interaksional didefefinisikan sebagai keadilan yang menyangkut hubungan antarpersonal dengan melihat bahwa sejauh mana pengambil keputusan atau supervisor memperlakukan karyawan dengan hormat dan kepekaan dalam menjelaskan alasan atas keputusan secara menyeluruh.

\section{Kinerja Manajerial}

Kinerja manajerial yang didefinisikan sebagai usaha yang diberikan oleh karyawan kepada perusahaan tempat bekerja guna mencapai tujuan perusahaan yang diharapkan. Kegiatan-kegiatan manajerial meliputi perencanaan, investigasi, pengkoordinasian, evaluasi, pengawasan, pengaturan staf, negosiasi dan perwakilan atau representasi (Mahoney et al., 1963) yang kemudian diredesain oleh Giri (2014), Subagiyo (2004) dan Tulus (2014). Instrumen yang digunakan dalam penelitian ini berbentuk kuesioner. Instrumen untuk mengukur masing-masing variabel mengikuti penelitian sebelumnya (Giri, 2014; Subagiyo, 2004; dan Tulus, 2014) yang mengambil objek penelitian di rumah sakit. Instrumen penelitian menggunakan skala likert 5 point dari skor 1 sampai skor 5 .

\section{Teknik Analisis Data}

Teknik analisis akan menjawab pertanyaan dengan cara bagaimana data yang telah dikumpulkan akan dianalisis untuk memberikan jawaban atas hipotesis yang telah dirumuskan (Supramono \& Utami, 2004). Pengolahan data menggunakan SPSS 20. Analisis data yang dilakukan dalam penelitian ini meliputi statistik deskriptif dan regresi dengan multiplemediator. Dalam analisis jalur, sudah dilakukan uji kualitas data melalui uji validitas dan reabilitas serta uji asumsi klasik.Pengujian hipotesis dalam penelitian ini menggunakan teknik analisis jalur (path analysis). Model jalur menggambarkan hubungan antara variabel independen, mediasi, dan dependen (Sunyoto, 2012). Analisis jalur merupakan perluasan dari analisis regresi linear berganda. Analisis jalur adalah penggunaan analisis regresi untuk menaksir hubungan kausalitas antar variabel (model kausal) yang telah diterapkan sebelumnya berdasarkan teori (Ghozali, 2009). Model penelitian ini menggunakan lebih dari satu variabel mediasi (multiplemediation) sehingga analisis penelitian tergambar melalui struktur jalur multiplemediation.

Kerangka penelitian digunakan untuk penelitian yang terdiri dua atau lebih mediator. Regresi dengan multiple mediator memasukkan lebih dari satu variabel mediasi kedalam model regresi (Ghozali, 2009). Model ini menggambarkan pengaruh total variabel independen terhadap variabel dependen (path a) dan total pengaruh variabel independen terhadap variabel dependen (path a') dan pengaruh tidak langsung variabel independen terhadap variabel dependen melalui variabel mediasi. Kerangka penelitian ini digambarkan secara struktural sebagai berikut. 


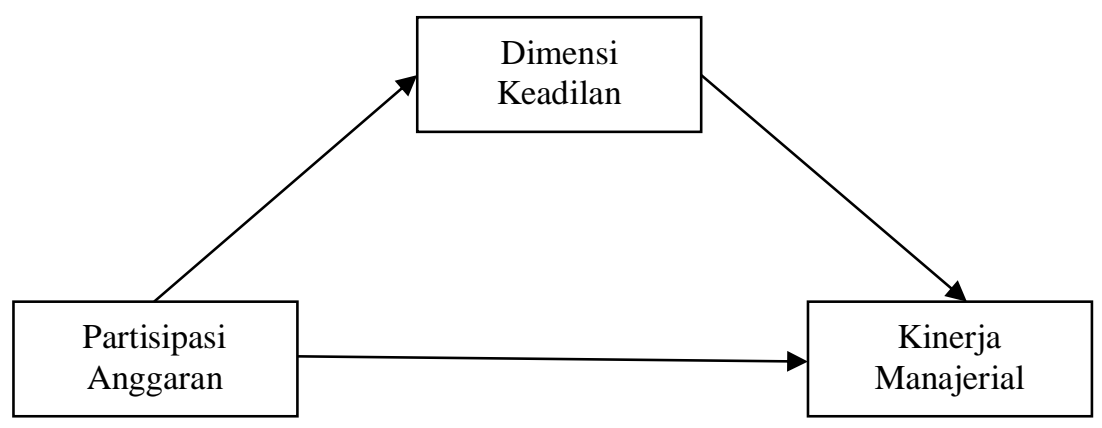

Gambar 1. Kerangka Penelitian

\section{HASIL PENELITIAN}

\subsection{Analisis Data}

Hasil analisis data menyajikan koefisien determinasi, t-statistic, dan hasil uji hipotesis. Koefisien determinasi mengukur seberapa jauh model dalam menerangkan variasi variabel independen. Adapun hasil dari koefisien determinasi yang disajikan pada Tabel 2.

Tabel 2. Koefisien Determinasi

\begin{tabular}{|l|c|}
\hline & $R$ square \\
\hline Keadilan Distribusi & 0,183 \\
\hline Keadilan Prosedural & 0,347 \\
\hline Keadilan Interaksional & 0,351 \\
\hline Kinerja Manajerial & 0,408 \\
\hline
\end{tabular}

Sumber: Data diolah

Berdasarkan tabel 2, koefisien determinasi R Square menunjukkan bahwa semakin tinggi nilai R2 berarti semakin baik model. Dengan kata lain, semakin besar kemampuan variabel independen menjelaskan variabel dependen, semakin baik persamaan structural.

Keadilan distributif menghasilkan $\mathrm{R}$ square sebesar 0,183 yang mengartikan bahwa pengaruh keadilan distributif terhadap partisipasi penganggaran sebesar $18,3 \%$, sedangkan sisanya sebesar $81,7 \%$ dipengaruhi oleh variabel lain di luar model penelitian. Keadilan prosedural menghasilkan $\mathrm{R}$ square sebesar 0,347 yang mengartikan bahwa pengaruh keadilan prosedural terhadap partisipasi penganggaran sebesar 34,7\%, sedangkan sisanya sebesar $65,3 \%$ dipengaruhi oleh variabel lain di luar model penelitian.Keadilan prosedural menghasilkan $\mathrm{R}$ square sebesar 0,351 yang mengartikan bahwa pengaruh keadilan prosedural terhadap partisipasi penganggaran sebesar $35,1 \%$, sedangkan sisanya sebesar 64,9\% dipengaruhi oleh variabel lain di luar model penelitian.Lebih lanjut, kinerja manajerial mampu dijelaskan oleh partisipasi penganggaran, keadilan distributif, keadilan prosedural, dan keadilan interaksional sebesar 0,408. Ini menunjukkan bahwa pengaruh keadilan distributif, keadilan prosedural, dan keadilan interaksional terhadap partisipasi penganggaran sebesar 40,8\%, sedangkan sisanya sebesar 59,2\% dipengaruhi oleh variabel lain di luar model penelitian. 
Tabel 3. Uji statistik t

\begin{tabular}{|c|c|c|c|}
\hline Model & Koefisien & t-statistic & Keterangan \\
\hline Partispasi anggaran $\rightarrow$ kinerja manajerial & 0,220 & 1,527 & Tidak signifikan \\
\hline Partispasi anggaran $\rightarrow$ keadilan distributif & 0,428 & $3,209 * * *$ & Signifikan \\
\hline Partispasi anggaran $\rightarrow$ keadilan prosedural & 0,589 & $4,942 * * *$ & Signifikan \\
\hline Partispasi anggaran $\rightarrow$ keadilan interaksional & 0,593 & $4,991 * * *$ & Signifikan \\
\hline Keadilan distributif $\rightarrow$ kinerja manajerial & 0,383 & $2,550 * *$ & Signifikan \\
\hline Keadilan prosedural $\rightarrow$ kinerja manajerial & 0,620 & $4,091 * * *$ & Signifikan \\
\hline Keadilan interaksional $\rightarrow$ kinerja manajerial & 0,727 & $5,037 * * *$ & Signifikan \\
\hline \multicolumn{4}{|l|}{ Signifikansi pada level $* * * 0,01, * * 0,05, * 0,10$} \\
\hline
\end{tabular}

Berdasarkan pada Tabel 3 di atas, hanya partisipasi anggaran yang tidak signifikan, sedangkan sisanya berada pada signifikansi pada level di bawah $10 \%$.

Tabel 4. Total efek mediasi

\begin{tabular}{|l|c|l|l|}
\hline \multicolumn{1}{|c|}{ Model } & Koefisien & t-statistic & Keterangan \\
\hline Partispasi anggaran $\rightarrow$ keadilan distributif $\rightarrow$ kinerja manajerial & 0,384 & $1,708 *$ & Signifikan \\
\hline Partispasi anggaran $\rightarrow$ keadilan prosedural $\rightarrow$ kinerja manajerial & 0,585 & $3,355^{*} * *$ & Signifikan \\
\hline Partispasi anggaran $\rightarrow$ keadilan interaksional $\rightarrow$ kinerja manajerial & 0,651 & $3,070 * * *$ & Signifikan \\
\hline Signifikansi pada level $* * * 0,01, * * 0,05, * 0,10$ & & \\
\hline
\end{tabular}

Sumber: Data diolah

Pada total efek mediasi yang ditunjukkan oleh tabel 4, semua mediator menghasilkan nlai t-hitung lebih besar dari nilai t-tabel.

\subsection{Hasil Uji Hipotesis}

Uji hipotesis dalam penelitian ini menggunakan model regresi multiple mediaton sebab penelitian ini memiliki tiga mediator. Model tersebut menggambarkan pengaruh total variabel independen terhadap variabel dependen ( $p a t h$ a) dan total pengaruh variabel independen terhadap variabel dependen (path a') dan pengaruh tidak langsung variabel independen terhadap variabel dependen melalui variabel mediasi. Adapun hasil uji hipotesis diringkas sebagai berikut.

Tabel 5. Hasil Uji Hipotesis

\begin{tabular}{|c|c|c|c|}
\hline & Prediksi Arah & Signifikansi & Hasil \\
\hline H1 & Positif & Tidak signifikan & Ditolak \\
\hline H2 & Positif & Signifikan & Diterima \\
\hline H3 & Positif & Signifikan & Diterima \\
\hline H4 & Positif & Signifikan & Diterima \\
\hline H5 & Positif & Signifikan & Diterima \\
\hline H6 & Positif & Signifikan & Diterima \\
\hline H7 & Positif & Signifikan & Diterima \\
\hline
\end{tabular}

\section{H1: Pengaruh Partisipasi Anggaran Terhadap Kinerja Manajerial}

Hasil uji hipotesis antara partisipasi anggaran terhadap kinerja manajerial menunjukkan koefisien sebesar 0,220 dengan arah positif. Artinya apabila partisipasi 
anggaran naik 1 skor, maka kinerja manajerial akan naik sebesar 0,220 dengan asumsi variabel yang lain dianggap constant. Hasil uji statistik t tidak menunjukkan signifikan pada level signifikansi yang ditetapkan. Dari hasil tersebut dapat ditarik kesimpulan bahwa tidak terdapat pengaruh signifikan partisipasi anggaran terhadap kinerja manajerial, sehingga Hipotesis1 ditolak.

\section{H2 : Pengaruh Keadilan Distributif Terhadap Kinerja Manajerial}

Hasil uji hipotesis antara partisipasi anggaran terhadap kinerja manajerial menunjukkan koefisien sebesar 0,428 dengan arah positif. Artinya apabila keadilan distributif naik 1 skor, maka kinerja manajerial akan naik sebesar 0,220 dengan asumsi variabel yang lain dianggap constant. Hasil uji statistik menunjukkan signifikansi pada level 0,01. Dari hasil tersebut dapat ditarik kesimpulan bahwa tidak terdapat pengaruh signifikan partisipasi anggaran terhadap kinerja manajerial, sehingga Hipotesis 2 diterima.

\section{H3 : Pengaruh Partisipasi Anggaran Terhadap Kinerja Manajerial}

Hasil uji hipotesis antara partisipasi anggaran terhadap kinerja manajerial menunjukkan koefisien sebesar 0,589 dengan arah positif. Artinya apabila keadilan prosedural naik 1 skor, maka kinerja manajerial akan naik sebesar 0,589 dengan asumsi variabel yang lain dianggap constant. Hasil uji statistik t menunjukkan signifikansi pada level 0,01. Dari hasil tersebut dapat ditarik kesimpulan bahwa tidak terdapat pengaruh signifikan partisipasi anggaran terhadap kinerja manajerial, sehingga Hipotesis 3 diterima.

\section{H4 : Pengaruh Partisipasi Anggaran Terhadap Kinerja Manajerial}

Hasil uji hipotesis antara partisipasi anggaran terhadap kinerja manajerial menunjukkan koefisien sebesar 0,593 dengan arah positif. Artinya apabila keadilan interaksional naik 1 skor, maka kinerja manajerial akan naik sebesar 0,593 dengan asumsi variabel yang lain dianggap constant. Hasil uji statistik t menunjukkan signifikansi pada level 0,01. Dari hasil tersebut dapat ditarik kesimpulan bahwa tidak terdapat pengaruh signifikan partisipasi anggaran terhadap kinerja manajerial, sehingga Hipotesis 4 diterima.

\section{H5: Pengaruh Keadilan Distributif Dalam Memediasi Hubungan Antara Partisipasi Anggaran Dan Kinerja Manajerial}

Hasil uji hipotesis mediator keadilan distributif dalam mempengaruhi hubungan antara partisipasi anggaran terhadap kinerja manajerial menunjukkan koefisien sebesar 0,384 dengan arah positif. Artinya apabila mediator keadilan distributif naik 1 skor, pengaruh partisipasi anggaran terhadap kinerja manajerial akan naik sebesar 0,384 . Hasil t-statistik lebih besar dari t-tabel $(1,708>1,684)$ yang signifikansinya berada pada level 0,10, Dari hasil tersebut dapat ditarik kesimpulan bahwa keadilan distributif berpengaruh signifikan dalam memediasi hubungan antara partisipasi anggaran terhadap kinerja, sehingga Hipotesis5 diterima.

H6: Keadilan Prosedural Dalam Memediasi Hubungan Antara Partisipasi Anggaran Dan Kinerja Manajerial 
Hasil uji hipotesis mediator keadilan prosedural dalam mempengaruhi hubungan antara partisipasi anggaran terhadap kinerja manajerial menunjukkan koefisien sebesar 0,585 dengan arah positif. Artinya apabila mediator keadilan prosedural naik 1 skor, pengaruh partisipasi anggaran terhadap kinerja manajerial akan naik sebesar 0,585. Hasil t-statistik lebih besar dari t-tabel $(3,355>2,704)$ yang signifikansinya berada pada level 0,01. Dari hasil tersebut dapat ditarik kesimpulan bahwa keadilan distributif berpengaruh signifikan dalam memediasi hubungan antara partisipasi anggaran terhadap kinerja manajerial, sehingga Hipotesis 6 diterima.

\section{H7: Pengaruh Keadilan Interaksional Dalam Memediasi Hubungan Antara Partisipasi Anggaran dan Kinerja Manajerial (H4)}

Hasil uji hipotesis mediator keadilan interaksional dalam mempengaruhi hubungan antara partisipasi anggaran terhadap kinerja manajerial menunjukkan koefisien sebesar 0,651 dengan arah positif. Artinya apabila mediator keadilan interaksional naik 1 skor, pengaruh partisipasi anggaran terhadap kinerja manajerial akan naik sebesar 0,651. Hasil t-statistik lebih besar dari t-tabel $(3,070>2,704)$ yang signifikansinya berada pada level 0,01. Dari hasil tersebut dapat ditarik kesimpulan bahwa keadilan interaksional berpengaruh signifikan dalam memediasi hubungan antara partisipasi anggaran terhadap kinerja manajerial, sehingga Hipotesis 7 diterima.

\subsection{Partisipasi Anggaran dan Kinerja Manajerial}

Hasil uji H1 menunjukkan bahwa partisipasi anggaran memberikan hasil positif yang tidak signifikan terhadap kinerja manajerial. Hasil tersebut menyatakan bahwa partisipasi anggaran tidak berpengaruh terhadap kinerja manajerial. Hasil tersebut menolak $\mathrm{H} 1$ yang menyatakan bahwa partisipasi anggaran berpengaruh terhadap kinerja manajerial. Meningkat atau menurunnya partisipasi dalam penyusunan anggaran tidak dapat mendorong kenaikan atau penurunan kinerja manajerial. Partisipasi anggaran yang dijelaskan oleh teori penetapan tujuan dalam penelitian ini tidak mampu mempengaruhi kinerja manajerial. Teori penetapan tujuan menganggap bahwa perilaku individu diatur oleh ide seseorang. Sasaran untuk menetapkan tujuan adalah tingkat kinerja yang ingin dicapai. Ternyata, seseorang yang berkomitmen mencapai tujuan belum tentu dapat mempengaruhi pencapaian kinerja. Keikutsertaan dalam penyusunan anggaran tidak dapat menjadi cara yang efektif untuk mencapai peningkatan kinerja.

Tidak ada pengaruh partisipasi anggaran terhadap kinerja manajerial tidak sejalan dengan penelitian Giri (2014) dan Subagiyo (2004), tetapi sejalan dengan penelitian Setyowati dan Purwantoro (2013) dan Tulus (2014). Semakin seringnya bawahan dilibatkan dalam penyusunan anggaran di instansi pemerintah rumah sakit, tidak selalu menunjukkan kinerja manajerial yang lebih baik. Sebaliknya semakin jarangnya bawahan yang berpartisipasi dalam penyusunan anggaran, tidak selalu menunjukkan kinerja manajerial yang lebih buruk. Sebab tidak ada pengaruh antara partisipasi anggaran dan kinerja manajerial.

\subsection{Dimensi Keadilan Terhadap Kinerja Manajerial Keadilan Distributif}

Uji H2 menyatakan bahwa keadilan distributif berpengaruh positif terhadap kinerja manajerial. Berdasarkan hasil uji signifikansi, pengaruh keadilan distributif terhadap kinerja manajerial adalah signifikan. Ini berarti keadilan distributif berpengaruh 
signifikan terhadap kinerja manajerial. Koefisien variabel menunjukkan arah positif. Ini berarti terdapat hubungan searah antara keadilan distributif dan kinerja manajerial, yaitu semakin tinggi keadilan distributif, semakin tinggi kinerja manajerial. Hasil ini menerima $\mathrm{H} 2$ yang menyatakan bahwa keadilan distributif berpengaruh terhadap kinerja manajerial. Keadilan distributif mengacu bentuk keadilan bagaimana sumber daya dan penghargaan dialokasikan atau didistribusikan. Hal ini tentunya mendorong peningkatan kinerja.

Penelitian ini tidak sejalan dengan hasil penelitian Tulus (2014) yang menemukan bahwa keadilan distributif tidak berpengaruh terhadap kinerja manajerial. Para karyawan membentuk opini yang berkaitan dengan skema pendistribusian apakah penghargaan itu adil atau tidak. Perhatian mengenai keadilan distributif dirasakan adil dari penempatan hasil-hasil atau pemberian penghargaan kepada para anggota organisasi. Keadilan distributif yang dirasakan oleh seseorang tentunya akan berakibat pada kinerja. Wilayah tanggung jawab dalam menerima anggaran yang sesuai dan dialokasikan secara tepat (distirbutif) mendorong peningkatan kinerja. Dengan demikian, keadilan distributif tentu mendorong peningkatan kinerja manajerial.

\section{Keadilan Prosedural}

Uji H3 menyatakan bahwa keadilan prosedural berpengaruh positif terhadap kinerja manajerial. Berdasarkan hasil uji signifikansi, pengaruh keadilan prosedural terhadap kinerja manajerial adalah signifikan. Ini berarti keadilan prosedural berpengaruh signifikan terhadap kinerja manajerial. Koefisien variabel menunjukkan arah positif. Ini berarti terdapat hubungan searah antara keadilan prosedural dan kinerja manajerial, yaitu semakin tinggi keadilan prosedural, semakin tinggi kinerja manajerial. Hasil ini menerima $\mathrm{H} 3$ yang menyatakan bahwa keadilan prosedural berpengaruh terhadap kinerja manajerial. Keadilan prosedural mengacu pada bentuk keadilan dari prosedur dan proses yang digunakan untuk membuat suatu alokasi keputusan.

Temuan ini tidak sejalan dengan hasil penelitian Tulus (2014) yang menemukan bahwa keadilan prosedural tidak berpengaruh terhadap kinerja manajerial. Peningkatan kinerja terjadi saat penerapan prosedur yang diterapkan secara konsisten dan sesuai dengan standar etik dan moralitas (prosedural) memberikan informasi yang akurat disampaikan dengan baik dan kepercayaan dari atasan ke bawahan. Dengan demikian, keadilan distributif mendorong peningkatan kinerja manajerial.

\section{Keadilan Interaksional}

Uji H4 menyatakan bahwa keadilan Interaksional berpengaruh positif terhadap kinerja manajerial. Berdasarkan hasil uji signifikansi, pengaruh keadilan interaksional terhadap kinerja manajerial adalah signifikan. Ini berarti keadilan interaksional berpengaruh signifikan terhadap kinerja manajerial. Koefisien variabel menunjukkan arah positif. Ini berarti terdapat hubungan searah antara keadilan interaksional dan kinerja manajerial, yaitu semakin tinggi keadilan interaksional, semakin tinggi kinerja manajerial. Hasil ini menerima $\mathrm{H} 4$ yang menyatakan bahwa keadilan interaksional berpengaruh terhadap kinerja manajerial. Keadilan interaksional berhubungan dengan perasaan yang dirasakan seseorang apakah sudah diperlakukan adil disaat implementasi prosedur.

GHasniasari \& Sholihin (2014) menyatakan bahwa keadilan interaksional menekankan pada informasi dan interpersonal Keadilan tersebut berfokus pada persepsi individu terhadap kualitas perlakuan interpersonal yang diterima selama berlakunya 
prosedur organisasi.. Keadilan interaksional berhubungan dengan harga diri dan komitmen afektif terhadap organisasi.Keadilan interaksional didefinisikan sebagai keadilan yang menyangkut hubungan antarpersonal pimpinan dengan karyawan yang meliputi tiga aspek, yaitu penghargaan, netralitas, dan kepercayaan (Faturocman, 2002). Bawahan harus memegang amanah yang diberikan oleh atasan sehingga bawahan bisa dipercaya oleh atasan. Sebaliknya, bawahan akan percaya kepada pemimpinnya, jika atasan menunjukkan kinerja yang baik dan konsisten dengan apa yang dijanjikannya. Interaksi antara bawahan dan pimpinan mendorong kerjasama yang baik. Dengan demikian, outcome dari keadilan interaksional adalah kinerja. Peningkatan kinerja sangat dipengaruhi oleh keadilan interaksional.

\subsection{Dimensi Keadilan dalam Partisipasi Penyusunan Anggaran dan Kinerja Manajerial \\ Keadilan distributif}

Hasil uji hipotesis 2 menunjukkan bahwa mediator keadilan distributif memberikan hasil positif yang signifikan dalam hubungan antara partisipasi anggaran dan kinerja manajerial. Hasil tersebut menyatakan bahwa mediator keadilan distributif mempengaruhi hubungan antara partisipasi anggaran dan kinerja manajerial. Hasil tersebut menerima hipotesis 2 yang menyatakan bahwa keadilan distributif memediasi hubungan antara partisipasi anggaran dan kinerja manajerial. Suatu organisasi cenderung menginginkan keadilan dalam proses bisnisnya. Pendekatan yang dilakukan dengan cara yang berbeda terhadap keadilan akan sangat berguna untuk menjelaskan bermacam perilaku dalam konteks organisasi pada saat ini. Didasarkan pada teori kontijensi, keadilan distributif menjadi penentu yang berpengaruh untuk meningkatkan kinerja manajerial. Ulupui (2005) menyatakan bahwa pendekatan kontinjensi menyebabkan adanya variabel-variabel lain yang bertindak sebagai variabel variabel mediasi. Peran keadilan distributif sangat berpengaruh terhadap hubungan antara penganggaran dan kinerja.

Hasil penelitian ini sejalan dengan Giri (2014). Partisipasi anggaran dapat berpengaruh pada kinerja manajerial melalui peran keadilan distributif sebagai mediator. Hal ini berarti keadilan distributif mampu memediasi hubungan antara partisipasi penganggaran dengan kinerja manajerial. Peningkatan partisipasi anggaran yang melibatkan bawahannya dapat mengakibatkan peningkatan persepsi keadilan distibutif, yang pada akhirnya akan mengakibatkan peningkatan kinerja manajerial. Semakin tinggi keadilan distributif, semakin tinggi pengaruh partisipasi manajer dalam meningkatkan kinerja manajerial di rumah sakit.

\section{Keadilan Prosedural}

Hasil uji hipotesis 3 menunjukkan bahwa mediator keadilan prosedural memberikan hasil positif yang signifikan dalam hubungan antara partisipasi anggaran dan kinerja manajerial. Hasil tersebut menyatakan bahwa mediator keadilan prosedural mempengaruhi hubungan antara partisipasi anggaran dan kinerja manajerial. Hasil tersebut menerima hipotesis 3 yang menyatakan bahwa keadilan prosedural memediasi hubungan antara partisipasi anggaran dan kinerja manajerial.

Didasarkan pada teori kontijensi, keadilan prosedural menjadi mediator dalam mendorong peran partisipasi anggaran untuk meningkatkan kinerja manajerial. Keadilan 
prosedural menjadi faktor kontingensi dalam mempengaruhi hubungan antara partisipasi anggaran dan kinerja manajerial.

Keadilan prosedural mampu memediasi hubungan antara partisipasi penganggaran dengan kinerja manajerial. Peningkatan partisipasi anggaran dapat meningkatkan kinerja manajerial melalui keadilan prosedural sebagai mediator. Hasil ini sejalan dengan Giri (2014). Keadilan prosedural memfokuskan pada respon yang berorientasi pada keadilan aturan dan prosedur yang ditetapkan oleh manajemen rumah sakit. Ketika keadilan prosedural diimplementasikan dengan baik, peran partisipasi anggaran dapat mempengaruhi peningkatan kinerja manajerial.

\section{Keadilan Interaksional}

Hasil uji hipotesis 4 menunjukkan bahwa mediator keadilan interaksional memberikan hasil positif yang signifikan dalam hubungan antara partisipasi anggaran dan kinerja manajerial. Hasil tersebut menyatakan bahwa mediator keadilan interaksional mempengaruhi hubungan antara partisipasi anggaran dan kinerja manajerial. Hasil tersebut menerima hipotesis 4 yang menyatakan bahwa keadilan interaksional memediasi hubungan antara partisipasi anggaran dan kinerja manajerial.Keadilan interaksional adalah bagian dari dimensi keadilan selain dari keadilan distributif dan keadilan prosedural. Didasarkan juga pada teori kontijensi, keadilan interaksional menjadi mediator dalam mendorong peran partisipasi anggaran untuk meningkatkan kinerja manajerial. Penekanan keadilan interaksional tentunya lebih personal. Apabila seseorang diberikan kewenangan berpartisipasi dalam penyusunan anggaran, orang itu akan berusaha memahami tujuan yang direncanakan. Semakin tinggi keadilan interaksional, semakin tinggi partisipasi anggaran dalam mempengaruhi peningkatan kinerja. Hasil penelitian sejalan dengan penelitian oleh Hasniasari \& Sholihin (2014) bahwa keadilan interaksional dapat memediasi hubungan antara partisipasi anggaran dan kinerja manajerial. Keadilan interaksional sepenuhnya memberikan pengaruh dari dasar peningkatan kinerja. Ketika perannya dilibatkan pada hubungan partisipasi anggaran dan kinerja, maka terjadi pengaruh partisipasi anggaran terhadap peningkatan kinerja.

\section{KESIMPULAN}

Partisipasi anggaran menyediakan efek langsung yang mendorong peningkatan terhadap kinerja manajerial rumah sakit. Pada dimensi keadialan, implementasi keadilan distributif memberikan pengaruh pada peningkatan kinerja manajerial. Keadilan distributif yang dirasakan oleh seseorang berdampak pada peningkatan kinerja. Sedangkan, dimensi keadilan prosedural menunjukkan bahwa implementasi keadilan prosedural memberikan pengaruh pada peningkatan kinerja manajerial. Ketika kondisi keadilan prosedural diterapkan dengan baik, kinerja mengalami peningkatan. Begitu pula keadilan interaksional yang mendorong peningkatan kinerja manajerial. Interaksi yang mendorong kerjasama yang baik mempengaruhi kualitas peningkatan kinerja. Pada efek mediasi, partisipasi anggaran menyediakan efek tidak langsung melalui dimensi keadilan di mana keadilan distributive, procedural dan interaksional mendorong peningkatan hubungan antara partisipasi penyusunan anggaran dan kinerja manajerial. Semakin tinggi implementasi dimensi keadilan, semakin tinggi efek hubungan partisipasi anggaran terhadap kinerja manajerial rumah sakit. 
Hasil penelitian ini memiliki beberapa implikasi adalah sebagai berikut. Pertama, penelitian ini secara teoretis menyediakan bukti atas kajian mengenai peran keadilan dalam mempertimbangkan kinerja. Dimensi keadilan yang terdiri dari keadilan distributif, prosedural, dan interaksional mampu menjadi faktor kontingensi. Kedua, penelitian ini secara praktis berimplikasi terhadap peningkatan mutu kinerja manajerial dengan mempertimbangkan dimensi keadilan.

Penelitian ini mengambil studi kasus pada rumah sakit di Provinsi Sulawesi Selatan yang dilakukan pada tiga tempat penelitian. Namun demikian, sampel yang didapatkan terbatas hanya 48 responden, sehingga tingkat generalisasi hasil penelitian ini masih rendah. Penelitian selanjutnya dapat menambah sampel penelitian dengan meneliti beberapa rumah sakit yang memiliki standar atau tipe yang sama, sehingga dapat meningkatkan generalisasi hasil penelitian. Pengembangan penelitian selanjutnya mempertimbangkan objek penelitian yang lebih luas dan menggunakan mediator lain seperti job relevant information (JRI) sebab ketersediaan informasi yang diperoleh dari partisipasi dala $\mathrm{m}$ penyusunan anggaran memungkinkan mempengaruhi kinerja manajerial.

\section{DAFTAR PUSTAKA}

Ambrose, Maureen L \& Schminke, M. (2009). The Role of Overall Justice Judgment in Organizational Justice Research: A Test of Mediation. Journal of Applied Pshycology, 94(2), 491-500.

Bastian, I. (2009). Sistem Akuntansi Sektor Publik. Jakarta: Salemba Empat.

Bawono, A. Dewi Ayu. (2008). Keadilan Prosedur dalam Hubungan antara Budgetary Goal Characteristic dan Kinerja Manajerial Pejabat Pemerintah Daerah. Jurnal Akuntansi dan Keuangan, 7(2), 151-161.

Brownell, P dan M. McInnes. (1986). Budgetary Participation, Motivation, and Managerial Performance. The Accounting Review, 49(4), 587-600.

Chalos, P., \& Poon, M. (2000). Participation and Performance in Capital Budgeting Teams. Behavioral Research in Accounting , 12, 199-229.

Damayanti, Titien. (2007). Pengaaaruh Komitmen Anggaran dan Kultur Organisasiona terhadap Hubungan Partisipasi Penganggaran dan Kinerja Manajerial pada Kondisi Strecth Target. Jurnal Akuntansi dan Auiditng Indonesia, 11 (1), 81-101.

Faturochman. (2002). Deprivasi Relatif: Rasa Keadilan dan Kondisi Psikologis Buruh Pabrik. Jurnal Psikologi, 25 (2), 1-15.

Giri, Made Dwi B.W. (2014). Pengaruh Partisipasi Penganggaran pada Kinerja Manajerial dengan Keadilan Distributif, Keadilan Prosedural dan Komitmen Tujuan Anggaran sebagai Variabel Pemediasi. Tesis, Universitas Udayana Bali.

Ghozali, Imam. (2009). Aplikasi Analisis Multivariate dengan Program SPSS. Cetakan IV. Semarang: Badan Penerbit Universitas Diponegoro. 
Greenberg, J. (1986). Determinants of Perceived Fairness of Performance Evaluations. Journal of Applied Psychology, 71, 340-342.

Greenberg, J. (1990). Organizational Justice : Yesterday, to Day, And Tomorrow. Journal of Management, 16(2), 399-432.

Hasniasari, R., \& Sholihin, M. (2014). Analisis Hubungan Penganggaran Partisipatif dan Kinerja: Pengujian Efek Mediasi Keadilan Persepsian dan Komitmen pada Lembaga Hukum Sektor Publik di Indonesia. Jurnal Akuntansi dan Keuangan , 23-32.

Indarto, Stefani L \& S. D. Ayu. (2011). Pengaruh Partisipasi dalam Penyusunan Anggaran terhadap Kinerja Manajerial Perusahaan melalui Kecukupan Anggaran, Komitmen Organisasi, Komitmen Tujuan Anggaran, dan Job Relevent Information (JRI). Seri Kajian Ilmiah, 14 (1).

Hidayah, Siti \& Haryani. (2013). Pengaruh Keadilan Distributif dan Keadilan Prosedural terhadap Kinerja Karyawan BMT Hudatama Semarang. Jurnal Ekonomi, Manajemen, dan Bisnis. 20 (35).

Indriantoro, Nur dan Bambang Supomo. 2014. Metodologi Penelitian Bisnis Untuk Akuntansi dan Manajemen. Edisi Pertama, Cetakan ke-12. Yogyakarta: Penerbit BPFE.

Kreitner, R. \& A. Kinicki. (2010). Organizational Behavior. New York, United State: McGraw-Hill 9th edition.

Locke E.A \& J.F Bryan. (1968). Goal-Setting as A Determinant of the Effect of Knowledge of Score on Performance. The American Journal of Psychology, 81(3), 398-406.

Locke, E.A \& G.P Latham. 1990. A Theory of Goal Setting and Task Performance. Englewood Cliffs. NJ: Prentice-Hall.

Mahoney, T, T.H Jerdee, \& S.J Carrol. (1963). Development of Managerial Development Performance. A Reserach Approach, South Western Publishing Company.

Mardiasmo. (2005). Akuntansi Sektor Publik. Yogyakarta: Andi Offset.

Milani, K. (1975). The Relationship pf Participation in Budget-Setting on Industrial Supervisor Performance and Attitudes: A Field Study. The Accounting Review, 50,104-123.

Muhlis. (2012). Pengaruh Partisipasi Penyusunan Anggaran terhadap Kinerja Aparatur Pemerintah Daerah dengan Budaya Organisasi dan Komitmen Organisasi sebagai Moderator (Studi Kasus pada Pemerintah Kabupaten Barru Sul-Sel). Tesis, Universitas Haasanuddin. 
Munandar, M. (1990). Budgeting, Perencanaan Kerja, Pengkoordinasian Kerja, Pengawasan Kerja. Yogyakarta: BPFE.

Munawar, Gugus Irianto, \& Nurkholis. (2006). Pengaruh Karakteristik Tujuan Anggaran terhadap Perilaku, Sikap, dan Kinerja Aparat Pemerintah Daerah di Kabupaten Kupang. Simposium Nasional Akuntansi 9 Padang.

Nadirsyah, M. R. Yahya, \& G. Putra. (2012). Faktor-faktor yang Mempengaruhi Kinerja Manajerial Satuan Kerja Perangkat Daerah (SKPD) pada Pemerintah Kabupaten Aceh Tengah. Jurnal Ekonomi dan Pembangunan, 3(1), 99-114.

Ogiedu, Killian O \& J. Odia. (2013). Relationship between Budget Participation, Budget Procedural Fairness, Organisational Commitment, and Managerial Performance. Review of Public Administration and Management, 1(3), 252-269.

Robbins, S.P \& T.A Judge. (2008). Perilaku Organisasi (Organizational Behaviour). Jakarta : Salemba Empat.

Sardjito, Bambang \& O. Muthaher. (2007). Pengaruh Partisipasi Penyusunan Anggaran terhadap Kinerja Aparat Pemerintah Daerah: Budaya Organisasi dan Komitmen Organisasi sebagai Variabel Moderating. Simposium Akuntansi Nasional X, Makassar.

Setyowati, Lilis \& Purwantoro. (2013). Analisis Pengaruh Partisipasi Penyusunan Anggaran terhadap Kinerja Manajerial dan Kepuasan Kerja pada Pemerintah Kota Semarang. Media Ekonomi \& Teknologi Informasi, 21(2), 66-79.

Subagiyo, Lilik. (2004). Pengaruh Partisipasi dalam Penyusunan Anggaran terhadap Kinerja Manajerial: Komitmen Tujuan sebagai Variabel Intervening (Studi Empiris pada Rumah Sakit Tipe A, B, dan C di Jawa Tengah dan Daerah Istimewa Yogyakarta). Tesis, Universitas Diponegoro.

Sugiyono. (2009). Metode Penelitian Bisnis. Bandung: Alfabeta.

Sunyoto, Danang. (2012). Model Analisis Jalur untuk Riset Ekonomi. Bandung: Yrama Widya.

Supramono \& Intiyas Utami. (2004). Desain Proposal Penelitian Akuntansi dan Keuangan. Yogyakarta: ANDI.

Susmitha, Y. (2012). Pengaruh Partisipasi Penyusunan Anggaran pada Kinerja Manajerial dengan Locus of Control dan Komitmen Organisasional sebagai variabel Pemoderasi (Studi Empiris pada Rumah Sakit Pemerintah di Provinsi Bali. Tesis, Universitas Udaya.

Tapatfeto, J. D. (2013). Analisis Komitmen Tujuan dan Partisipasi Penyusunan Anggaran terhadap Kinerja Manajerial. Jurnal Akuntansi Multiparadigma , 4(30), 330-507. 
Tulus, Agung. (2014). Pengaruh Partisipasi Anggaran, Keadilan Distributif, Keadilan Prosedural, serta Goal Commitmen terhadap Kinerja Manajerial (Studi Empiris pada RSUD Dr. Adhyatma, MPH Semarang). E-journal, Universitas Dian Nuswantoro Semarang.

Wahyuningsih, Sulung dan Bambang A. Pramuka. (2012). Determinan Partisipasi Penganggaran dan Pengaruhnya terhadap Kinerja Manajerial Aparat Pemerintah Daerah Kabupaten Banyumas. Jurnal Akuntansi \& Auditing, 1(1), 1-96.

Wentzel, Kristin. (2002). The Influence of Fairness Perception and Goal Commitment on Managers Performance in A Budget Setting. Behaviour Research in Accounting, 14, 247-271.

Winata, L., \& Mia, L. (2005). Information Technology and the Performance Effect of Managers' Participation in Budgeting: Evidence from the Hotel Industry. International Journal of Hospitality Management , 24(1), 21-39. 